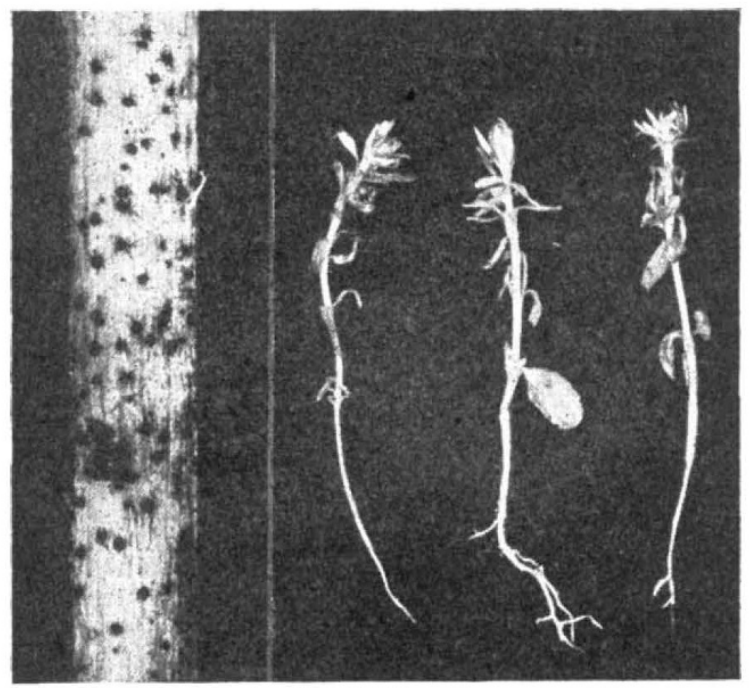

LEFT, FLAX STEM $(\times 6)$ SHOWING PYCNIDIA of Phoma sP. RIGHT, FLAX SHEDIINGS ATTACKED BY Phoma sP.

used at the rate of $12 \mathrm{oz}$. per cwt. of seed. The short wet method of seed treatment using an 8 per cent solution of 'Ceresan U.564' at 0.9 gall. per cwt., although more effective than treatment with 'Nomersan', still did not provide adequate control. Further trials have been made using 'Arasan' (50 per cent tetra-methyl-thiuram disulphide), 'New Improved Ceresan' (5 per cent ethyl-mercury-phosphate), 'Fermate' (ferric dimethyldithiocarbamate) and 'Spergon' (98 per cent tetrachloro-para-benzoquinone). Of these materials promising results have been given" by 'New Improved Ceresan' and 'Arasan'. Using 'New Improved Ceresan' at the rates of $12 \mathrm{oz}$. and $9 \mathrm{oz}$. per cwt. of seed, the contamination of a seed sample was reduced from $32 \cdot 6$ to $2 \cdot 0$ per cent and $5 \cdot 5$ per cent respectively. 'Arasan' used at the same rates reduced contamination to $10 \cdot 8$ per cent and 14.5 per cent. In the case of 'Arasan' it is of interest to note that the duration of the test had to be extended from seven to twelve days as this disinfectant exerts an inhibiting effect upon the fungus. No such effect was noted in the case of 'New Improved Ceresan' which appears to be more directly toxic. Whereas 'New Improved Ceresan' showed generally powerful fungicidal and bactericidal activity, the same selectivity was noted in the case of 'Arasan' as with other disinfectants with tetra-methyl-thiuram disulphide as the active constituent; in the case of bacteria and some fungi these materials have little or no effect.

Although it has not yet been possible to arrange for field trials with these materials, the high degree of correlation obtained between the results from laboratory and field trials in the case of $C$. linicola and $P$. Lin $i^{7}$ suggest that results obtained in the laboratory should also be closely applicable in the field in the case of Phoma. It is proposed to adopt the use of both 'Arasan' and 'New Improved Ceresan' on a commercial scale during 1945. Of all the disinfectants tested for flax, 'New Improved Ceresan' offers the greatest promise for seed-borne diseases generally, its only drawback being its poisonous nature when compared with 'Arasan' and 'Nomersan'.

Tests made with samples of seed treated with 'Arasan' or 'New Improved Ceresan' at the rate of $12 \mathrm{oz}$. per cwt. have shown that such treatment has no effect upon germination. No adverse effects upon germination have been observed after treated. seed has been stored for eight weeks either in small packets in the laboratory or in hundredweight lots subject to ordinary storage conditions. In all cases the moisture content of the seed used was below 10 per cent.

A. E. Muskett.

J. Colmoun.

Plant Disease Division,

Ministry of Agriculture (N.I.),

The Queen's University,

Belfast. Jan. 19.

'Pethybridge, G. H., Lafferty, H. A., and Rhynehart, J. G., J. Dept. Agric. Irel., 21, 167 (1921).

' Millikan, C. R., J. Austral. Inst. Agric. Sei., 10, 129 (1944).

3 Muskett, A. E., and Malone, J., Ann. Appl. Biol., 28, 8 (1941).

- Muskett, A. E., and Colhoun, J., Ann. Appl. Biol., 30, 7 (1943).

5 Muskett, A. E., and Colhoun, J., Nature, 146, 32 (1940).

- Muskett, A. E. and Colhoun, J., Nature, 147, 176 (1941).

? Muskett, A. E., and Colhoun, J., Ann. Bot., (N.S.), 6, 219 (1942)

\section{A Method of Estimating the Activity of Spermatozoa}

IN view of the absence of any satisfactory method for the quantitative estimation of the motility of spermatozoa, it is believed that the following method, evolved in relation to work on human semen, may prove of interest.

The semen is diluted with warm phosphate-glucose solution ${ }^{1}$ (one in twenty gives a satisfactory dilution for semen containing 70-200 million sperm per c.c.). The dilution is thoroughly mixed by bubbling air through it with a pipette. One drop of fluid is placed on each of two Thoma counting slides. Over one drop is inverted a small straight-sided glass capsule lined with filter paper moistened with 2 per cent osmic acid. The osmic vapour permanently immobilizes all the sperm in about ten seconds. The capsule is removed, and cover slips are placed on both drops, taking the usual precautions to avoid running over. If the capsule is kept upside down on a glass plate, one drop of osmic acid will last about six hours.

The slides are put aside to allow the sperm to settle, that with the motile sperm being placed on a warmed microscope stage. After five minutes this slide is examined and a count made of the immobile, and of the feebly moving but non-progressive sperm in 160 small squares. The two figures thus obtained may be stated as $x$ and $y$ respectively. The actively moving sperm are ignored. A count is then made on the osmicated slide of all the sperm in 160 small squares, giving a figure $z$. Subtraction of $x+y$ from $z$ gives the number of active sperm in the suspension corresponding to a total number of $\operatorname{sperm} z$, and a volume of fluid contained in 160 small squares.

Sperm which have been cold for an hour or longer do not all become active immediately when mixed with warm diluting fluid, and maximum motility may not be reached until the dilution has been kept at $37^{\circ} \mathrm{C}$. for an hour.

When repeated estimations of motility are required during the course of an experiment, it is essential to take two drops for comparison each time, as clumping or disintegration may cause a progressive reduction in the total number of sperm in the suspension.

This work has been assisted by a research grant from the Family Planning Association.

Zoology Department,

University College,

Exeter. Jan. 5 .

${ }^{2}$ Chang, M. and Walton, A., Proc. Roy. Soc., B, 129, 517 (1940). 